【論 文】

UDC : 69. $025: 624.072 .2 .012: 620.1$

\title{
合成スラブ用デッキプレートの溝に埋め込まれた スタッドコネクタの押抜き試験
}

$\begin{array}{lllll}\text { 正会員 } & \text { 平 } & \text { 野 } & \text { 道 } & \text { 勝* } \\ \text { 正会員 } & \text { 穂 } & \text { 積 } & \text { 秀 } & \text { 雄** } \\ \text { 正会員 } & \text { 伊 } & \text { 藤 } & & \text { 学*** } \\ \text { 正会員 } & \text { 藤 } & \text { 岡 } & & \text { 宏**** } \\ \text { 正会員 } & \text { 延 } & \text { 命 } & \text { 慶 } & \text { 穂***** } \\ \text { 正会員 } & \text { 伊 } & \text { 藤 } & \text { 善 } & \text { 三****** }\end{array}$

\section{1. 序}

1.1 はじめに

本研究は，デッキプレートとコンクリートとの合成ス ラブを合成ばりに用いる場合を想定し，主として，デッ キプレートの溝底を貫通して溶接されたスタッドコネク 夕の挙動の把握を目的に, 押し抜き試験 (図一1) を行っ たものである。

すなわち，スタッドコネクタのずれ耐力およびずれ剛 性にスタッドコネクタの径, 一溝中のスタッドコネクタ の本数およびデッキプレートのせい等が及ぼす影響を明 らかにしようとするものである。

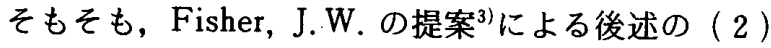
式は，溝中のスタッドコネクタの耐力式として広く知ら れているが，この耐力式には疑問ももたれており ${ }^{8)}$ ま た，物理的意味も不明瞭といわざるを得ない。一方，最 近, Hawkins, N.M. 等は, 耐力の決定要因としてコン クリートのコーン状破壊があることに注目し，この破壊 相に対して，アンカーボルトの引き抜き耐力" と同一思 想の耐力式を提案した4)。しかしながら，この考え方に 従って耐力を論じた報告は今のところほかになく，多く の検討が必要な段階と考える。このように，合成スラブ 用デッキプレートを用いる場合はもちろんのこと，一般 用デッキプレートを用いる場合においても，残された研 究課題は多いものと思われる。

ところで，合成スラブ用デッキプレートには，コンク

本報告は, 昭和 60 年度大会 (東海) での実験結果の報告1)を 詳述し，考察を加えたものである。

* 東京理科大学 教授・工博

** 東京理科大学 助手

*** 東京理科大学 大学院生

**** 日鉄建材工業(株) 製品開発部開発第一室・室長

****** 日鉄建材工業(株) 製品開発部開発第一室・課長

******* 日鉄建材工業(株) 製品開発部開発第一室・係長 (昭和 61 年 5 月 9 日原稿受理

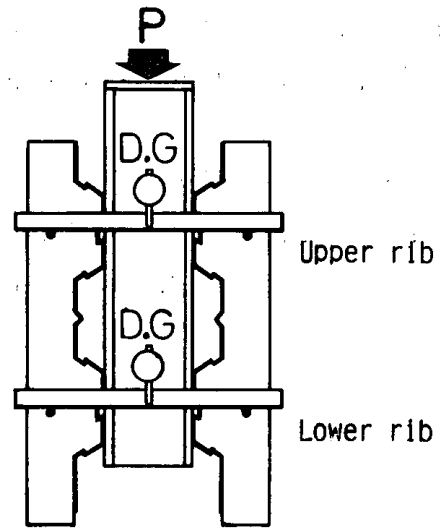

$P:$ load

DG: Dial Goune

Fig. 1 Test set-up

リートとの合成効果を期待する鍵溝等が溝底部の中央に 存在するものが多く，スタッドコネクタの打設はこれら を避けるのが現実的と思われる。スタッドコネクタが溝 中心にないよき，せん断力の作用方向がずれ耐力に影響 を及ぼすものと考えられる。本実験では，一溝当たり 1 本のスタッドコネクタの試験体においてこの影響を検討 することとし，一溝当たり 2 本もしくは 3 本のスタッド コネクタの試験体では，せん断力の作用方向がずれ耐力 に影響しないように，スタッドコネクタを配置した。

実験結果を検討したところ，溝中央にスタッドコネク 夕を配する通常の場合にも当てはまるであろう多くの興 味ある知見が得られた。コーン破壊で決定づけられる耐 力が，デッキプレートの溝底をかさ上げした仮想断面へ のコーン投影面積に比例するという結果を得たこともそ の一つである。本論文は，これらの新知見を報告するも のである。

\section{2 実験の経緯}

実験は 3 期にわたって行われた。最初の実験は, 本報 


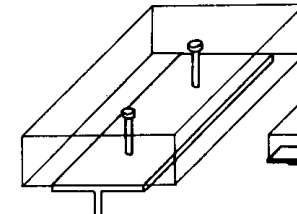

(a)

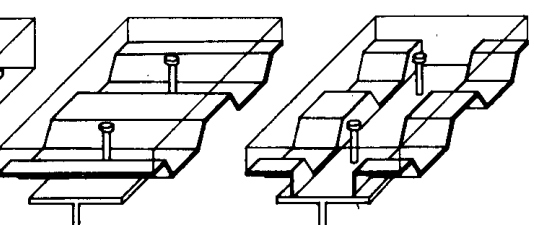

( b )

(c)
Fig. 2 Types of slabs

告書でシリーズ I と呼ばれる 14 体の試験体によるもの である。

この最初の実験において, Fisher, J.W. の耐力式 ${ }^{3}$ の適用が困難であること，また，当時，Hawkins， N.M. らの報告4)がなされていなかったことから，詳細 な研究の必要性が感じられた。このため, シリーズIII して 42 体からなる実験を行った。

なお，シリーズ I の実験で一部の試験体において，試 験体のスラブ幅の狭いことに起因する溝上面でのコンク リートのせん断破壊 (図一9（c) 参照) が観察され，また， 一部の試験体では, 実験の最終段階で下溝（図一1 参照） の破壊が上溝のそれよりも激しく, 上下の溝でスタッド コネクタの耐力負担の異なることが懸念された。このた め; スラブ幅を拡げた試験体と, 一溝にのみスタッドコ ネクタを溶接した試験体を用いて予備実験を行った。こ こでは，この実験をシリーズ【と呼ぶことにする。

\section{3 耐力式および設計指針など}

スタッドコネクタのずれ耐力に関する既往の成果を概 括すると,まず, Fisher, J.W.らは, 図一2(a) に示す 等厚スラブ中でのスタッドコネクタの最大耐力 $q_{s o l}$ の 算定式として次式を提案している21。

$$
q_{s o t}=0.5_{s c} a \sqrt{E_{c} \cdot F_{c}} \text {. }
$$

${ }_{s c} a$ : スタッドコネクタの軸部断面積

$E_{c}, F_{c}$ : コンクリートのヤング係数および圧縮強度 また，同図（b）に示す鋼ばりに直交するデッキプレー トの溝中のスタッドコネクタの耐力 $q_{r b b}$ として, 溝断 面の形状とスタッドコネクタの本数により, 上式を低減 する次式を与えている゙๋。

$$
q_{r \iota b}=\frac{0.85}{\sqrt{n_{d}}} \frac{L-H_{d}}{H_{d}} \frac{b_{d}}{H_{d}} \cdot q_{s o l} \leqq q_{s o l}
$$

$n_{d}$ : 一溝中のスタッドコネクタの本数

$b_{d}, H_{d}:$ デッキプレートの平均溝幅とせい

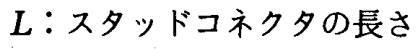

Hawkins, N. M. , Mitchell, D. は, 同じく, 図一2(b) の場合を対象に，スタッドコネクタが破断する破壊にた いして上述の（1）式を, また, コンクリートのコーン 破壊に対して, 次式

$$
q_{\text {cone }}=1.43 A_{c}^{\prime} \sqrt{F_{c}}
$$

$A_{c}^{\prime}:$ コーン表面積 $\left(\mathrm{cm}^{2}\right)$

$F_{c}$ : コンクリートの现縮強度 $\left(\mathrm{kg} / \mathrm{cm}^{2}\right)$

を提案し、コーン破壊の場合に, 最大耐力以降の耐力の
劣化の激しいことと, 交番繰返し載荷による最大耐力が, 単調載荷による耐力を下まわることを報告(4)してる。

スタッドコネクタおよびデッキプレートの幅が等しい 場合に，デッキプレートのせいが深いほど，（2）式は 低い耐力を与え，（3）式は高い耐力を与える。

平野・穂積ほかは，デッキプレートが鋼ばり上で断続 する図一2(c) の場合に対して，耐力が（1）式で与え 得ることを報告5)している。

設計指針に示された耐力式に注目すると, AISC $\mathrm{Spec}^{7)}$ は，スタッドコネクタの長さ $L$ と軸径 $d$ の比 $L / d$ を 4.0 以上 $(L / d \geqq 4.0)$ とする制約のもとに, 図 一2(a)に対して（1）式を，また，同図（b) に対し て（2）式を採用している。

わが国の指針 ${ }^{8)}$ は，これにならうとともに，わが国で の施工例の多い同図 (c) に対して，同じく（1）式を 与えている。

ECCS Recom. ${ }^{10)}$ は，限界設計法を採用し，同図(っ に関する耐力式として次式を示している*1。

$$
\begin{aligned}
L / d \geqq 4.2 \quad q_{s o l} & =\frac{0.36 d^{2} \sqrt{E_{c} \cdot F_{c}}}{\gamma_{m c}} \\
& \leqq \frac{0.7 \pi(d / 2)^{2} f_{y}}{\gamma_{m s}} \\
L / d=3.0 \quad \dot{q}_{s o l} & =\frac{0.28 d^{2} \sqrt{E_{c} \cdot F_{c}}}{\gamma_{m c}} \\
& \leqq \frac{0.7 \pi(d / 2)^{2} f_{y}}{\gamma_{m s}}
\end{aligned}
$$

$(L / d=3.0$ から $L / d=4.2$ の間は直線補完）

$f_{y}$ : スタッドコネクタの降伏点

終局に対して $\gamma_{m c}=1.3, \gamma_{m s}=1.0$

上式は,ずれ耐力をスタッドコネクタの純せん断耐力で 制限したもので興味深い。また，同図（b）に対しては， 同じく（2）式を与えている(ただし， $q_{\text {sol }}$ は (4) 式)。

一方，道路橋に注目すると，わが国の道路橋示方書 ${ }^{11}$ は,スタッドコネクタの長い場合に対して, Viest, I. M. の研究成果 ${ }^{6)}$ と同一思想の (5-1) 式を採用し，短 い場合に対して，支圧面積に比例する（5-2）式を用い ている。

$$
\begin{array}{ll}
L / d \geqq 5.5 & q_{\text {sol }}=30 d^{2} \sqrt{F_{c}} \cdots \\
L / d<5.5 & q_{\text {sol }}=5.5 d L \sqrt{F_{c}}
\end{array}
$$

上式は, 許容せん断力で, 一般に破壊に対して 6 以上の 安全率を持つとされている。

$\mathrm{AASHTO}^{12)}$ は, $L / d \geqq 4$ に対して, (5-1) 式と同様に, $d^{2} \sqrt{F_{c}}$ に比例する耐力式を採用してきたが, 1977 年に

*1 その後, 同一思想のもとに若干の修正が施され, EUROCODE 4 の武案に示された。

CEC : EUROCODE 4 COMPOSITE STEEL AND CONCRETE STRUCTURES - print draft, October 1984 
（1）式に改めた。

以上のように，（1）式および（2）式の採用が世界 の趨勢と思われる。

\section{2. 実験方法}

\section{1 試験体名称}

本報告書の試験体の名称に関する約束は; 図一 3 に示 したとおりである。個体の識別において図中○で囲まれ た記号は省略を原則とする。

なお，この約束は適宜転用する。例えば，D $50 \mathrm{~A}$ は， せいが $50 \mathrm{~mm}$ のデッキプレートを持つAタイプの試験 体の総称である。

\section{2 試験体}

試験体は，表一1 に示す総数 62 体である。実験に用 いたデッキプレートは図一 4 に示す 3 タイプ 6 種類であ る。EZ およびXタイプは合成スラブ用のデッキプレー トで，鍵溝，エンボスが存在し，一般のデッキプレート より広い溝幅を有する。鍵溝もしくはエンボスがコンク

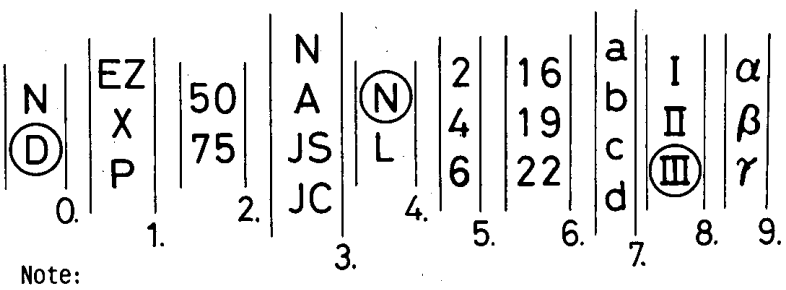

0. (D):W1 th Decks

N : Soljd Slab without Deck

1. Type of Decks

2. Helght of Decks

3. Type of Slabs

4. (1): Normol-Weight Concrete $L$ : Lightwelght Concrete

5. Number of Studs per Shear Plane

6. Stud Dlameter

7. Location of Studs in Ribs of Specimens with two Studs per Shear Plane

8. Series Number

9. Type of Specimens of Series II

(D), (1), (II) are omitted

Fig. 3 Naming of specimen

Table 1 Test specimens

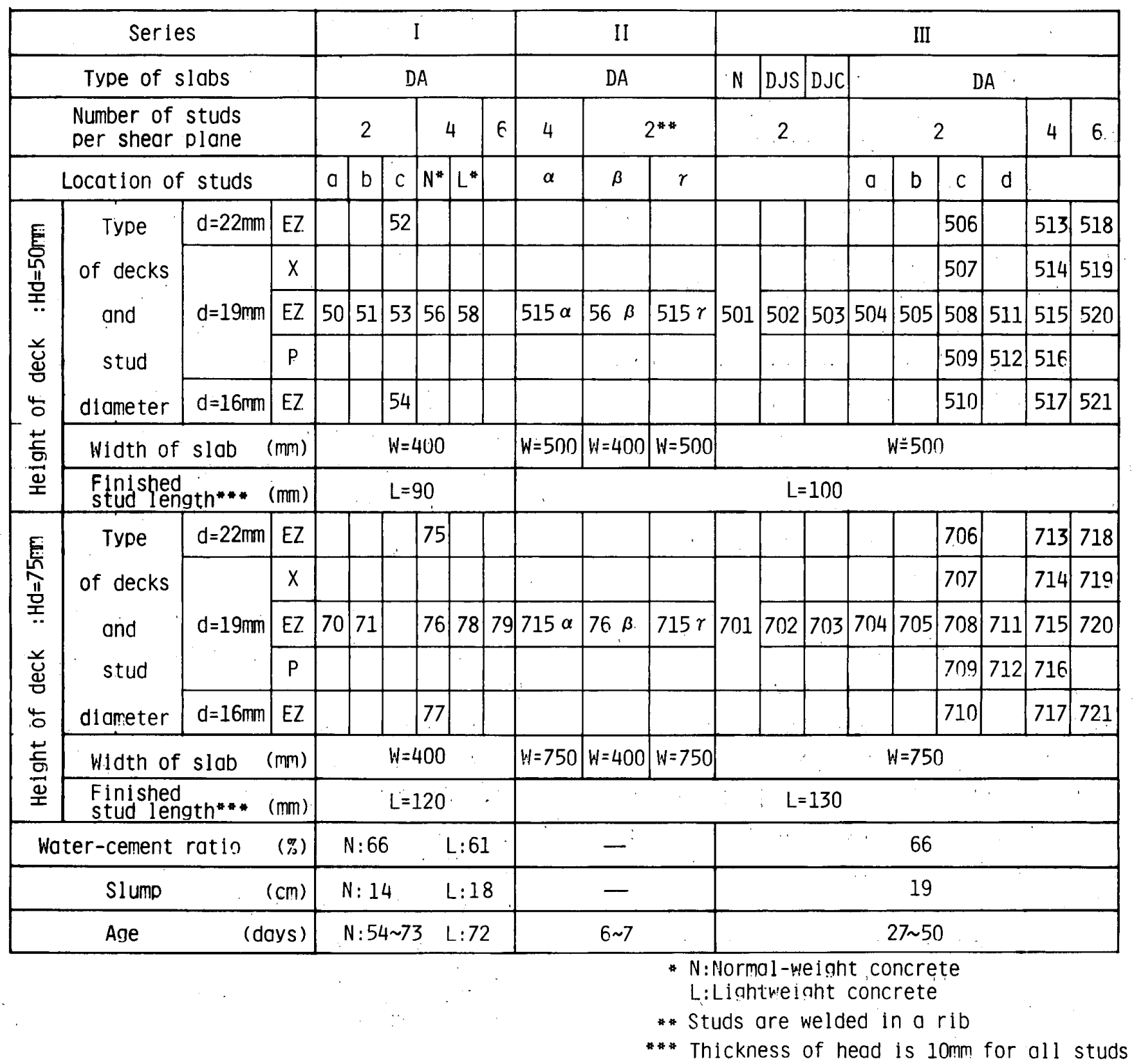



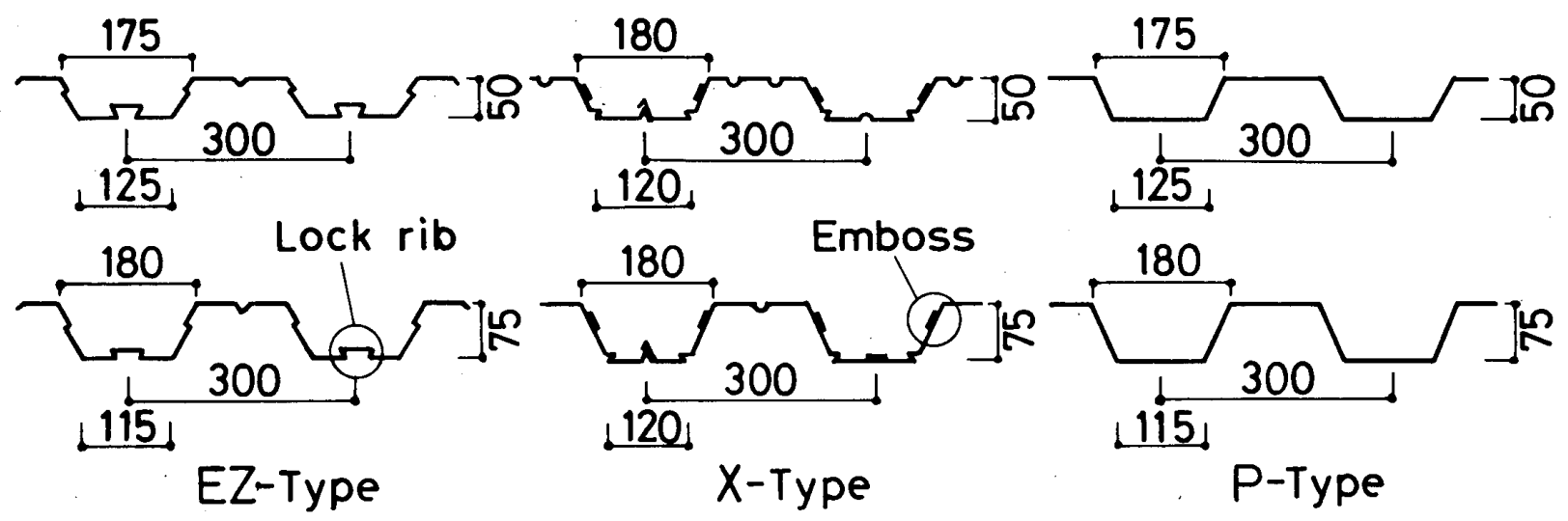

Fig. 4 Profiles of steel decks

リートの亀裂を誘発し，耐力へ影響することが懸念され たために，それらのないPタイプを市販の鋼板からプレ ス加工により作成した。シリーズ【および吕における EZ 50 を除いて, 亜鉛メッキがなされている。なお,デッ キプレートの板厚はすべて $1.2 \mathrm{~mm}$ である。
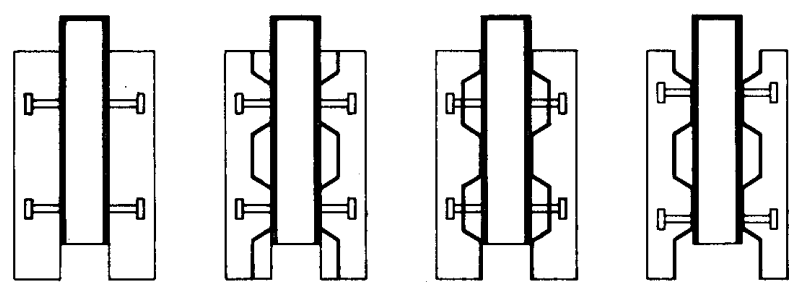

試験体をそのスラブ形状により分類すると，図一 5 に 示す 4 種類となる。スラブ厚はデッキプレートの山上で $80 \mathrm{~mm}$ とした。 $\mathrm{N}$ タイプすなわち等厚スラブでは, 80 $\mathrm{mm}$ にデッキプレートのせい $50 \mathrm{~mm}$ もしくは $75 \mathrm{~mm}$ を 加えた値とし, 試験体の名称には, この 50 もしくは 75

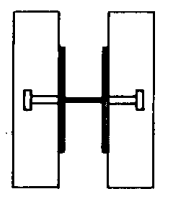

N-Type

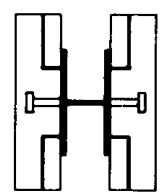

DJS-Type

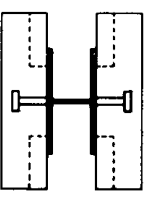

DJC-Type

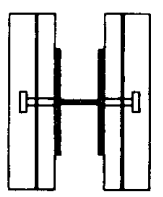

DA-Type

Fig. 5 Types of slabs

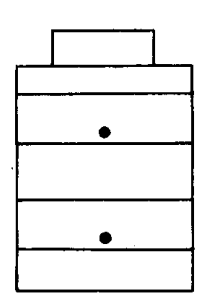

a-Type

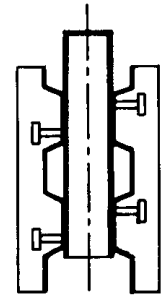

a b

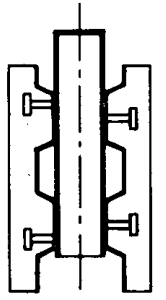

c $\mathrm{d}$

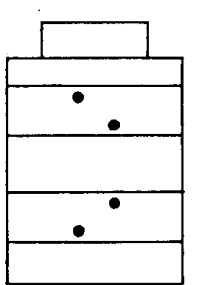

$\frac{1}{5 d}$
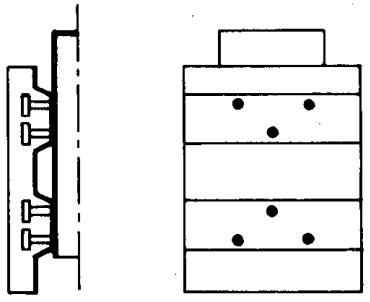

$1+1$

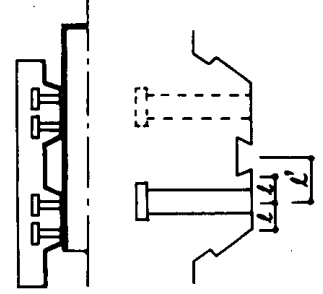

d: Stud diameter

(a) Two studs per shear plane

(b) four studs per shear plane (c) six studs per shear plane

(d)

Fig. 6 Location of stud connectors

の数值を用いた。DJ タイプの試験体では, 発泡スチロー ルをコンクリートの流出止めの小口ふっざとした。

No. 58 (EZ 50 AL 419 I ), No.78 (EZ 75 AL 419 I ) は，一種軽量コンクリートを用い，ほかはすべて普通コ ンクリートを用いた。シリーズIでは, 散水シート掛け 養生としたが，シリーズ【およびII では蒸気促進養生を 行った。なお，水セメント比，スランプおよび試験時の 材令は表一1に示したとおりである。

スラブの補強筋比は, 実構造物のスラブ筋比を勘案し, CP $117^{* 2}$ をも参照して定めた。その配筋にあたっては, コーン破壊を想定したときに形成されるであろうコーン を鉄筋が貫通することのないよう配虑した。

スタッドコネクタの径は, $\phi 16, \phi 19, \phi 22$ の 3 種類 *2 文献 8)，10）中にも紹介されている。


Fig. 7 Types of specimens of series II 
とした。その長さは，表一1に示したとおりである。片 側スラブ当たりのスタッド本数は，2，4，6本，すなわ ち一溝当たり $1 ， 2 ， 3$ 本とした。デッキプレートが鋼ば り上で連続しているDAタイプにおけるスタッドコネ クタは，デッキプレートに先穴加工を行わずに溝底部を 貫通して溶接した。なお，次に述べるdタイプ，すなわ ち, 溝中心にスタッドコネクタを配置する試験体のうち, EZ タイプは鍵溝を貫通して溶接することからスタッド コネクタのアークシールドの幅で鍵溝を切り取った。

$\mathrm{EZ}$ タイプおよびXタイプでは，鍵溝等の存在により， スタッドコネクタを溝中心に溶接することが非現実的で あるから，一溝当たり 2 本もしくは 3 本のスタッドコネ クタをもつ試験体では，図一6に示すように，その配置 は千鳥とし，上溝と下溝で対称配置とした。また，一溝 当たり 1 本の試験体では, 加力方向との関係で, スタッ ドコネクタと溝側面までの距離が問題となることから, 同図(a)に示す $\mathrm{a}$ から d 4 種類の配置形態を計画した。

溝断面に対するスタッドコネクタの位置は, EZ タイ プに対して同図 (d) とし，XタイプおよびPタイプに 対しては, 溝中心からスタッドコネクタの心までの距離 を同図中の $l^{\prime}$ と等しく定めた。

シリーズIは，前述のように予備実験として行った。 図一7(a) の試験体は，スラブ幅を十分広くして, 溝上 面でのコンクリートのせん断破壊を防止することによ り，スタッドコネクタの実ずれ耐力の観察が可能である ことを検証するためのものである。

同図（b) の試験体は, シリーズ I の No.56（EZ 50 A 419 I ) と No.76 (EZ 75 A 419 I ) から上溝中のスタッ ドコネクタを取除き，下溝のみのずれ耐力を観察するこ とを目的としたものである。

また，同図 (c) は，この予備実験で，上下の溝の耐 力負担が異なった場合に備えて, 新たな試験体の形態を 模索するために用意したものである。

試験体の詳細は図一8に示したとおりである。図中ス タッドコネクタの配置は, 同一断面, 同一配筋の試験体 のうち, 一例を示すものである。

Table 2 Properties of stud connectors

\begin{tabular}{|c|c|c|c|c|c|c|}
\hline \multicolumn{3}{|c|}{ Specimen } & \multirow{2}{*}{$\begin{array}{l}\text { U1timate } \\
\text { strenath } \\
\left(\mathrm{kg} / \mathrm{mm}^{2}\right)\end{array}$} & \multirow{2}{*}{$\begin{array}{l}0.2 \mathrm{wleld} \\
\text { strennth } \\
\left(\mathrm{kg} / \mathrm{mm}^{2}\right)\end{array}$} & \multirow{2}{*}{$\begin{array}{c}\text { Young's } \\
\text { modulus } \\
\times 10^{4} \\
\left(\mathrm{~kg} / \mathrm{mm}^{2}\right)\end{array}$} & \multirow{2}{*}{$\begin{array}{c}\text { Coefficient } \\
\text { of extension } \\
\text { (\%) }\end{array}$} \\
\hline Series & $\begin{array}{r}\text { Helght } \\
\text { of deck } \\
(\mathrm{mm})\end{array}$ & $\begin{array}{c}\text { Diometer } \\
\text { (mm) }\end{array}$ & & & & \\
\hline \multirow{2}{*}{1} & 50 & $\begin{array}{l}22 \\
19 \\
1 \epsilon\end{array}$ & $\begin{array}{l}40.0 \\
41.7 \\
46.4\end{array}$ & $\begin{array}{l}34.8 \\
30.6 \\
31.1\end{array}$ & $\begin{array}{l}2.09 \\
2.0 € \\
2.10\end{array}$ & $\begin{array}{l}31.9 \\
42.8 \\
40.9\end{array}$ \\
\hline & 75 & $\begin{array}{l}22 \\
19 \\
16 \\
\end{array}$ & $\begin{array}{l}39.3 \\
38.7 \\
45.1 \\
\end{array}$ & $\begin{array}{l}35.1 \\
28.5 \\
30.4\end{array}$ & $\begin{array}{l}2.14 \\
2.05 \\
2.16 \\
\end{array}$ & $\begin{array}{l}29.4 \\
39.5 \\
39.8 \\
\end{array}$ \\
\hline \multirow[b]{2}{*}{ 旦 } & 50 & \multirow{2}{*}{19} & 46.4 & 28.5 & 2.03 & 46.4 \\
\hline & 75 & & 47.2 & 33.5 & 1.88 & 28.4 \\
\hline \multirow{2}{*}{ m } & 50 & $\begin{array}{l}22 \\
19 \\
16\end{array}$ & $\begin{array}{l}41.7 \\
49.1 \\
47.9\end{array}$ & $\begin{array}{l}32.3 \\
33.6 \\
32.2\end{array}$ & $\begin{array}{l}1.94 \\
2.04 \\
1.91\end{array}$ & $\begin{array}{l}34.5 \\
28.1 \\
28.9\end{array}$ \\
\hline & 75 & $\begin{array}{l}22 \\
19 \\
16\end{array}$ & $\begin{array}{l}41.9 \\
44.0 \\
46.7\end{array}$ & $\begin{array}{l}33.9 \\
31.0 \\
32.4\end{array}$ & $\begin{array}{l}1.95 \\
2.05 \\
1.89 \\
\end{array}$ & $\begin{array}{l}34.2 \\
38.6 \\
28.8 \\
\end{array}$ \\
\hline
\end{tabular}

\section{3 材料試験}

表一 5 中に，コンクリートの圧縮試験の結果を示す。 ヤング係数は，ひずみゲージにより計測された $1 / 3 f_{c}$ 割線係数である。同一のシリーズで值が異なるのは，主
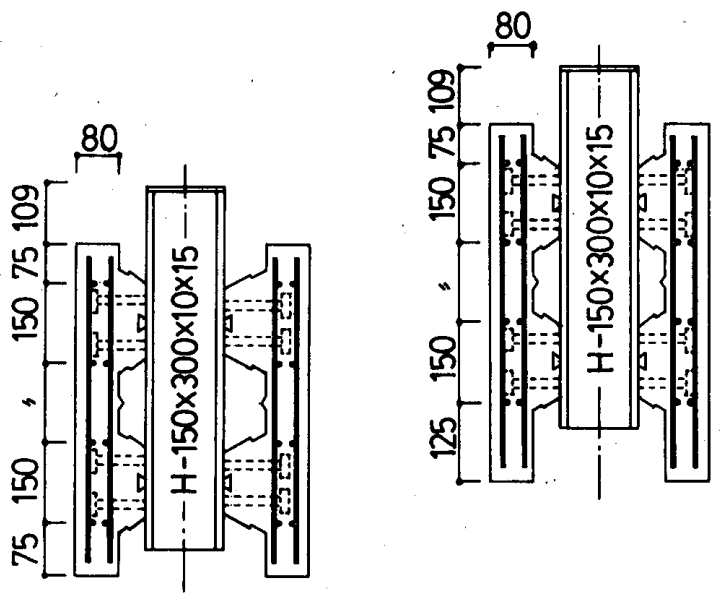

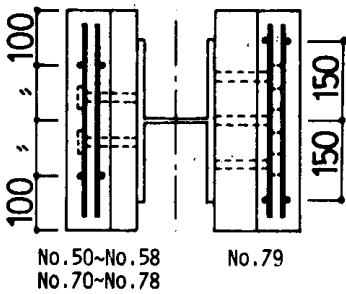

(a)
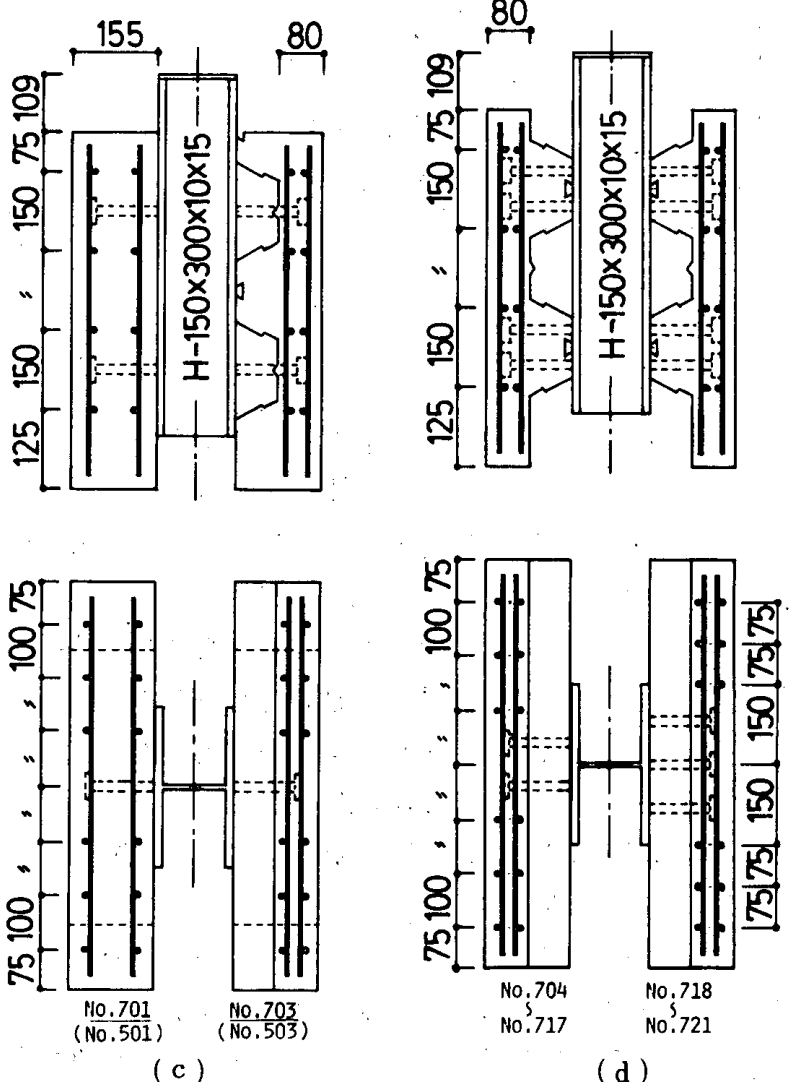

(d)

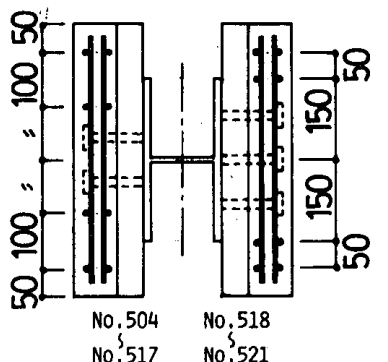

(b)



Fig. 8 Details of specimens 
Table 3 Properties of steel decks

\begin{tabular}{|c|c|c|c|c|c|}
\hline \multicolumn{2}{|c|}{ Specimen } & \multirow{2}{*}{$\begin{array}{l}\text { Ultimate } \\
\text { strength } \\
\left(\mathrm{kg} / \mathrm{mm}^{2}\right)\end{array}$} & \multirow{2}{*}{$\begin{array}{c}0.27 \text { yield } \\
\text { strenath } \\
\left(\mathrm{kg} / \mathrm{mm}^{2}\right)\end{array}$} & \multirow{2}{*}{\begin{tabular}{|} 
Young's \\
modulus \\
$\times 10^{4}$ \\
$\left(\mathrm{~kg} / \mathrm{mm}^{2}\right)$
\end{tabular}} & \multirow{2}{*}{$\begin{array}{c}\text { Coefficient } \\
\text { of extension } \\
(7)\end{array}$} \\
\hline Series & $\begin{array}{c}\text { Type } \\
\text { of deck }\end{array}$ & & & & \\
\hline \multirow[b]{2}{*}{1} & EZ50 & 36.1 & $\frac{19}{29.7}$ & 1.87 & 32.3 \\
\hline & E775 & 36.4 & 28.7 & 1.82 & 30.5 \\
\hline \multirow{4}{*}{ III' } & EZ50 & 35.9 & 26.2 & 2.03 & 37.3 \\
\hline & EZ75 & 49.5 & 31.8 & 1.99 & 29.7 \\
\hline & $\times 50$ & 44.2 & 30.4 & 1.90 & 30.5 \\
\hline & $\times 75$ & 44.2 & 34.7 & 1.80 & 29.1 \\
\hline
\end{tabular}

Table 4 Properties of deformed bars

\begin{tabular}{|c|c|c|c|c|}
\hline \multicolumn{2}{|c|}{ Specimen } & \multirow{2}{*}{$\begin{array}{l}\text { Ul timate } \\
\text { strength } \\
\left(\mathrm{kg} / \mathrm{mm}^{2}\right)\end{array}$} & \multirow{2}{*}{$\begin{array}{c}\text { Yield } \\
\text { strength } \\
\left(\mathrm{kg} / \mathrm{mm}^{2}\right)\end{array}$} & \multirow{2}{*}{$\begin{array}{l}\text { Coefflcient } \\
\text { of extension } \\
(\%)\end{array}$} \\
\hline Series & $\begin{array}{l}\text { Nominal } \\
\text { dlameter }\end{array}$ & & & \\
\hline I & D8 & 42.7 & 28.4 & 22.0 \\
\hline II & D10 & 1 & 43.5 & 24.2 \\
\hline III & D10 & 57.1 & 41.0 & 25.8 \\
\hline
\end{tabular}

に, 試験時の材令の違いによる。

スタッドコネクタの引張試験は, 4 号試験片（径：D $=5 \mathrm{~mm}$, 標点間距離 $: L=3.54 \mathrm{D})$ を削り出して用いた。 結果は，表一2に示したとおりである。いずれのスタッ ドコネクタにも降伏棚はなく，表中の耐力は，永久伸び $\varepsilon=0.2 \%$ に対応する。

デッキプレートおよび鉄筋の試験結果は，表一 3 およ び表一4に示したとおりである。おな，シリーズＩの鉄 筋D8 は SD 24 と思われる。

\section{4 載荷および測定方法}

載荷は油圧万能試験機により，シリーズ Iでは片振漸 増載荷，シリーズIおよび吕では単調載荷とした。

荷重は，試験機荷重指針もしくはロードセルにより読 み取った。コンクリートスラブと鋼ばりの相対ずれは, シリーズIでは，表裏各 1 個のダイヤルゲージにより， 溝間隔の中央 (一溝当たり 1 本の場合には，上下の溝中 のスタッド間隔の中央）で測定した。シリーズIIおよび IIIでは，表裏各 2 個のゲージにより，上下の溝中心（1 本の場合も含めて）で測定した（図一1参照）。

なお，鋼ばりとコンクリートスラブの分離を防止する 開き止めは用いていない。

\section{3. 結果と考察}

\section{1 破壊相}

観察された破壊相は次のとおりである。

1）スタッド破断（図一 $9(\mathrm{a})$, Stud failure)

2) コーン破壊 (図一9(b), Concrete pullout failure) : コンクリートのコーン状破壊

3）溝上面でのせん断破壊（図一9(c)，Rib-shearing failure）：試験体の全スラブ幅にわたって，溝上面 でコンクリートがせん断破壊される破壊相

4）溝側面の支圧破壊（図一9(d)，Rib-punching failure)：デッキプレートの溝側面の変形をともな う破壊相

これらの破壊相は，複合して観察されることも多く， また，1）および4）の破壊相では，デッキプレートの 局所的な破断（図一9(e)）を伴う場合もあった。なお， これらの破壊相は，大変形後に鋼柱部分とスラブ部分を 分離して観察したものであり，載荷中に観察された最大 耐力を決定づける耐力機構とは, 後述のように, 必ずし も一致しないと考えられる。

各試験体において観察された破壊相は，表一5の（6） （（9）欄に示したとおりである。なお，スタッド破断 の欄中に示された数値は, 破断した本数を示し，そのう

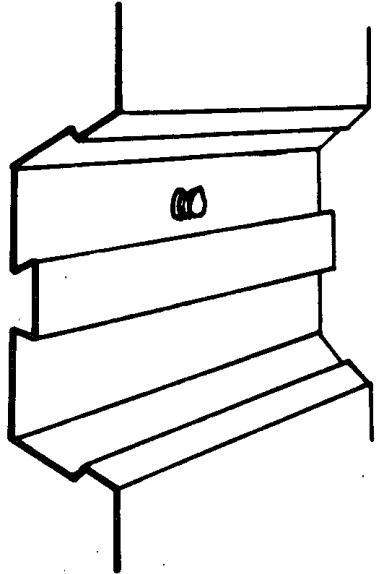

(a) Stud failure

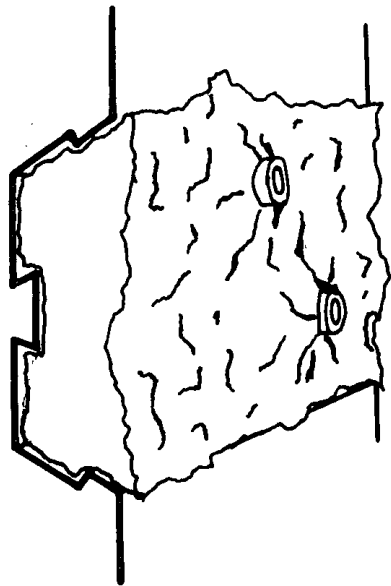

(c) Rib-shearing failure

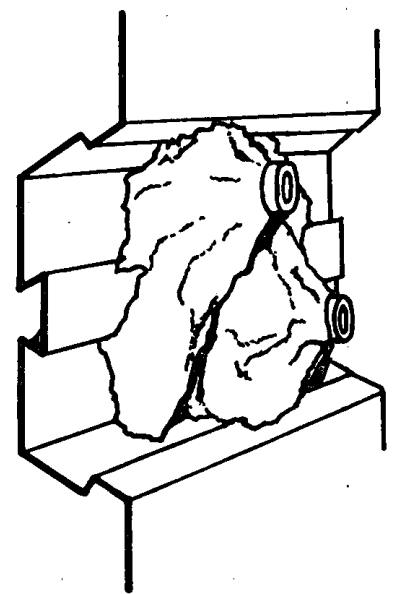

(b) Concrete pullout failure

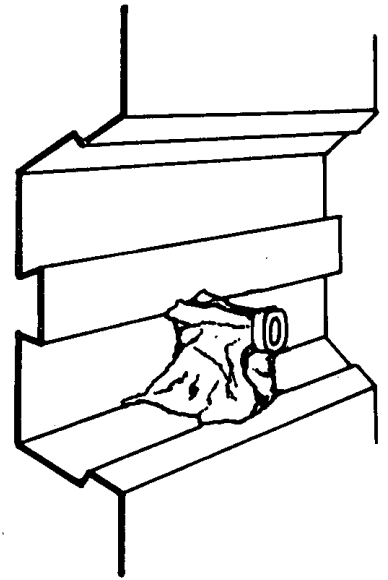

(d) Rib-punching failure

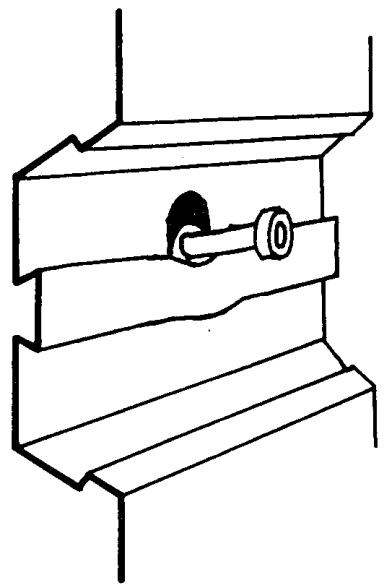

(e) Partial failure of deck

Fig. 9 Failure mode 
Table 5 Results of tests

\begin{tabular}{|c|c|c|c|c|c|c|c|c|c|c|c|c|}
\hline \multirow[b]{2}{*}{ Series } & \multirow[b]{2}{*}{ No. } & \multirow[b]{2}{*}{ Specimen } & \multirow{2}{*}{$\begin{array}{c}\text { Compress ive } \\
\text { strength } \\
\mathrm{fc} \\
\left(\mathrm{kg} / \mathrm{cm}^{2}\right) \\
(4)\end{array}$} & \multirow{2}{*}{$\begin{array}{c}\text { Young's } \\
\text { modulus } \\
\text { Ec } \\
\times 10^{5} \\
\left(\mathrm{~kg} / \mathrm{cm}^{2}\right) \\
(5) \\
\end{array}$} & \multicolumn{5}{|c|}{ Failure mode * } & \multicolumn{2}{|c|}{ Ultimate strength } & \multirow{2}{*}{$\begin{array}{c}\begin{array}{c}\text { Initial } \\
\text { stiffness } \\
\text { at } \\
\frac{1}{3} \cdot(\mathrm{Pu} / \mathrm{N}) \\
(\mathrm{t} / \mathrm{mm}) \\
(13)\end{array} \\
\end{array}$} \\
\hline & & & & & $\begin{array}{l}C \\
(6) \\
\end{array}$ & $\begin{array}{c}S \\
(7) \\
\end{array}$ & $\begin{array}{l}\mathrm{RS} \\
(8) \\
\end{array}$ & RP & $\begin{array}{c}C \\
o r \\
S \\
\text { (1n) }\end{array}$ & $\begin{array}{c}\text { per rib } \\
\text { Pu/N } \\
(t) \\
(11)\end{array}$ & $\begin{array}{c}\text { at Pu } \\
\delta_{u} \\
(\mathrm{~mm}) \\
(12)\end{array}$ & \\
\hline \multirow{2}{*}{ I } & $\begin{array}{l}50 \\
51 \\
52 \\
53 \\
54 \\
56 \\
58\end{array}$ & 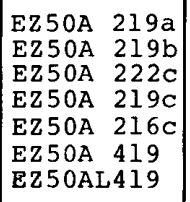 & $\begin{array}{l}\downarrow \\
280 \\
262\end{array}$ & $\begin{array}{l}\downarrow \\
2.38 \\
1.53\end{array}$ & $\begin{array}{l}0 \\
8 \\
8 \\
8 \\
0 \\
0\end{array}$ & $\begin{array}{l}1 \\
1 \\
2(1)\end{array}$ & 10 & 0 & $\begin{array}{l}c \\
c \\
C \\
c \\
- \\
c \\
c\end{array}$ & $\begin{array}{r}9.0 \\
8.9 \\
12.3 \\
9.7 \\
7.7 \\
17.1 \\
14.6\end{array}$ & $\begin{array}{l}4.54 \\
4.11 \\
2.48 \\
8.35 \\
2.01 \\
1.93 \\
2.15\end{array}$ & \\
\hline & $\begin{array}{l}70 \\
71 \\
75 \\
76 \\
77 \\
78 \\
79\end{array}$ & $\begin{array}{ll}\text { EZ75A } & 219 a \\
\text { EZ75A } & 219 \mathrm{~b} \\
\text { EZ75A } & 422 \\
\text { EZ75A } & 419 \\
\text { EZ75A } & 416 \\
\text { EZ75AL } & 419 \\
\text { EZ75A } & 619\end{array}$ & $\begin{array}{l}280 \\
\uparrow \\
280 \\
262 \\
280\end{array}$ & $\begin{array}{l}2 . \uparrow^{38} \\
2.38 \\
1.53 \\
2.38\end{array}$ & $\begin{array}{l}0 \\
0 \\
0 \\
0\end{array}$ & 1 & $\begin{array}{l}8 \\
8 \\
0 \\
0\end{array}$ & 0 & $\begin{array}{l}c \\
- \\
c \\
c \\
c \\
c \\
-\end{array}$ & $\begin{array}{r}5.3 \\
10.2 \\
13.3 \\
14.0 \\
13.3 \\
13.6 \\
21.0\end{array}$ & $\begin{array}{l}1.81 \\
1.31 \\
2.04 \\
2.64 \\
2.19 \\
3.23 \\
1.74\end{array}$ & \\
\hline \multirow{2}{*}{ II } & $\begin{array}{r}515 \alpha \\
56 \beta \\
515 \gamma\end{array}$ & $\begin{array}{ll}\text { EZ50A } & 419 \alpha \\
\text { EZ50A } & 219 \beta \\
\text { EZ50A } & 219 \gamma\end{array}$ & $\begin{array}{l}191 \\
1 \\
191\end{array}$ & $\begin{array}{l}1.75 \\
1 \\
1.75\end{array}$ & 8 & & & & $\begin{array}{l}c \\
c \\
C\end{array}$ & $\begin{array}{l}15.9 \\
15.1 \\
15.5\end{array}$ & $\begin{array}{l}3.23 \\
3.88 \\
2.85\end{array}$ & \\
\hline & $\begin{array}{r}715 \alpha \\
76 \beta \\
715 \gamma \\
\end{array}$ & $\begin{array}{|ll|}\text { EZ75A } & 419 \alpha \\
\text { EZ75A } & 219 \beta \\
\text { EZ75A } & 219 r \\
\end{array}$ & $\begin{array}{c}203 \\
\uparrow \\
203\end{array}$ & $\begin{array}{l}1.75 \\
1.75\end{array}$ & $\begin{array}{l}0 \\
0\end{array}$ & & & 0 & $\frac{c}{c}$ & $\begin{array}{l}13.5 \\
15.4 \\
13.4\end{array}$ & $\begin{array}{l}7.45 \\
5.05 \\
5.45\end{array}$ & \\
\hline \multirow{4}{*}{ III } & $\begin{array}{l}501 \\
502 \\
503 \\
504 \\
505 \\
506 \\
507 \\
508 \\
509 \\
510\end{array}$ &  & \multirow[t]{2}{*}{$\begin{array}{c}203 \\
211 \\
211 \\
203 \\
\uparrow\end{array}$} & \multirow[t]{2}{*}{$\begin{array}{c}1.99 \\
1.95 \\
1.95 \\
1.99 \\
\uparrow\end{array}$} & \multirow{2}{*}{$\begin{array}{l} \\
8 \\
8 \\
0 \\
0 \\
8 \\
\\
8 \\
8 \\
8 \\
0 \\
8 \\
8 \\
8 \\
8 \\
0\end{array}$} & $\begin{array}{l}1(1) \\
1\end{array}$ & \multirow[b]{2}{*}{0} & \multirow[t]{2}{*}{$\begin{array}{l}0 \\
0 \\
8 \\
0 \\
0\end{array}$} & $\begin{array}{l}\mathrm{S} \\
\mathrm{S} \\
\mathrm{S} \\
\mathrm{C} \\
\mathrm{C} \\
\mathrm{C} \\
\mathrm{C} \\
\mathrm{C} \\
\mathrm{C} \\
\mathrm{S}\end{array}$ & $\begin{array}{r}11.3 \\
10.8 \\
9.2 \\
6.6 \\
11.0 \\
8.9 \\
9.1 \\
9.3 \\
8.8 \\
6.7(6.8)\end{array}$ & \begin{tabular}{|c|}
10.88 \\
16.81 \\
10.57 \\
2.91 \\
5.02 \\
3.24 \\
4.6 \\
5.79 \\
3.4 \\
$5.07(17.54)$
\end{tabular} & $\begin{array}{l}16.9 \\
24.4 \\
27.0 \\
33.7 \\
20.7 \\
58.7 \\
13.1\end{array}$ \\
\hline & $\begin{array}{l}511 \\
512 \\
513 \\
514 \\
515 \\
516 \\
517 \\
518 \\
519 \\
520 \\
521\end{array}$ & $\begin{array}{ll}\text { EZ50A } & 219 \mathrm{~d} \\
\mathrm{P} 50 \mathrm{~A} & 219 \mathrm{~d} \\
\mathrm{EZ} 50 \mathrm{~A} & 422 \\
\mathrm{X} 50 \mathrm{~A} & 419 \\
\mathrm{EZ50A} & 419 \\
\mathrm{P} \text { 50A } & 419 \\
\mathrm{EZ50A} & 416 \\
\mathrm{EZ50A} & 622 \\
\mathrm{X} 50 \mathrm{~A} & 619 \\
\mathrm{EZ50A} & 619 \\
\text { EZ50A } & 616\end{array}$ & & & & $2(2)$ & & & $\begin{array}{l}c \\
C \\
C \\
C \\
C \\
C \\
C \\
C \\
C \\
C \\
C\end{array}$ & $\begin{array}{l}7.5(7.8) \\
7.6 \\
16.1 \\
16.5 \\
14.1 \\
14.8 \\
13.4 \\
20.9 \\
19.8 \\
19.2 \\
16.6\end{array}$ & $\begin{array}{l}7.48(27.05) \\
6.33 \\
4.63 \\
4.51 \\
4.84 \\
7.51 \\
3.83 \\
2.57 \\
2.96 \\
4.02 \\
4.2\end{array}$ & $\begin{array}{l}41.7 \\
84.4 \\
53.7 \\
36.7 \\
52.2 \\
37.9 \\
29.8 \\
58.1 \\
30.0 \\
53.3 \\
61.5\end{array}$ \\
\hline & $\begin{array}{l}701 \\
702 \\
703 \\
704 \\
705 \\
706 \\
707 \\
708 \\
709 \\
710\end{array}$ & $\begin{array}{lll}\mathrm{N} & 75 \mathrm{~N} & 219 \\
\mathrm{EZ75JS} & 219 \\
\mathrm{EZ75JC} & \mathrm{J} 219 \\
\mathrm{EZ75A} & 219 \mathrm{a} \\
\mathrm{EZ75A} & 219 \mathrm{~b} \\
\mathrm{EZ75A} & 222 \mathrm{C} \\
\mathrm{X} & 75 \mathrm{~A} & 219 \mathrm{C} \\
\mathrm{EZ} 75 \mathrm{~A} & 219 \mathrm{C} \\
\mathrm{P} & 75 \mathrm{~A} & 219 \mathrm{C} \\
\mathrm{EZ} 75 \mathrm{~A} & 216 \mathrm{C}\end{array}$ & \multirow[t]{2}{*}{$\begin{array}{c}211 \\
238 \\
\uparrow\end{array}$} & \multirow[t]{2}{*}{$\begin{array}{l}1.95 \\
2.19 \\
\uparrow\end{array}$} & \multirow{2}{*}{$\begin{array}{l} \\
0 \\
0 \\
0 \\
0 \\
0 \\
0 \\
\\
0 \\
0 \\
8 \\
8 \\
0 \\
8 \\
0 \\
0 \\
0\end{array}$} & $\begin{array}{l}2 \\
2 \\
3 \\
1 \\
1(1) \\
2(2) \\
2(1)\end{array}$ & & \multirow[t]{2}{*}{0} & $\begin{array}{l}\text { S } \\
\text { S } \\
\text { S } \\
\text { C } \\
\text { C } \\
\text { C } \\
\text { C } \\
\text { C } \\
\text { C } \\
\text { S }\end{array}$ & $\begin{array}{l}15.5 \\
12.8 \\
15.0 \\
6.2(7.3) \\
9.9(10.9) \\
9.6 \\
8.5 \\
8.1(9.6) \\
7.7 \\
6.4\end{array}$ & \begin{tabular}{|l}
25.5 \\
18.55 \\
30.83 \\
$3.6(26.83)$ \\
$3.11(38.01)$ \\
3.36 \\
4.86 \\
$5.32(28.54)$ \\
4.22 \\
3.61
\end{tabular} & $\begin{array}{l}14.8 \\
27.5 \\
24.6 \\
25.8 \\
22.5 \\
51.3 \\
23.7\end{array}$ \\
\hline & $\begin{array}{l}711 \\
712 \\
713 \\
714 \\
715 \\
716 \\
717 \\
718 \\
719 \\
720 \\
721\end{array}$ & 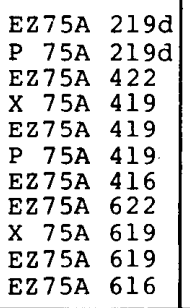 & & & & $\begin{array}{l}1 \\
1(1)\end{array}$ & & & $\begin{array}{l}C \\
C \\
C \\
C \\
C \\
C \\
C\end{array}$ & $\begin{array}{l}7.6(11.1) \\
9.6 \\
17.1 \\
14.1 \\
15.2 \\
14.5 \\
13.0(13.6) \\
21.7 \\
19.7 \\
19.6 \\
16.4\end{array}$ & $\begin{array}{l}6.12(38.53) \\
5.31 \\
5.06 \\
2.71 \\
5.2 \\
4.99 \\
5.38(25.02) \\
4.91 \\
4.3 \\
4.72 \\
4.46\end{array}$ & $\begin{array}{r}23.0 \\
29.1 \\
30.0 \\
26.1 \\
101.3 \\
53.7 \\
31.0 \\
90.4 \\
43.8 \\
43.6 \\
49.7\end{array}$ \\
\hline
\end{tabular}

* C:Concrete pulinut failure S: Stud follure RS:Rib-sheoring failure $R P: R i b-p u n c h i n n$ fallure 


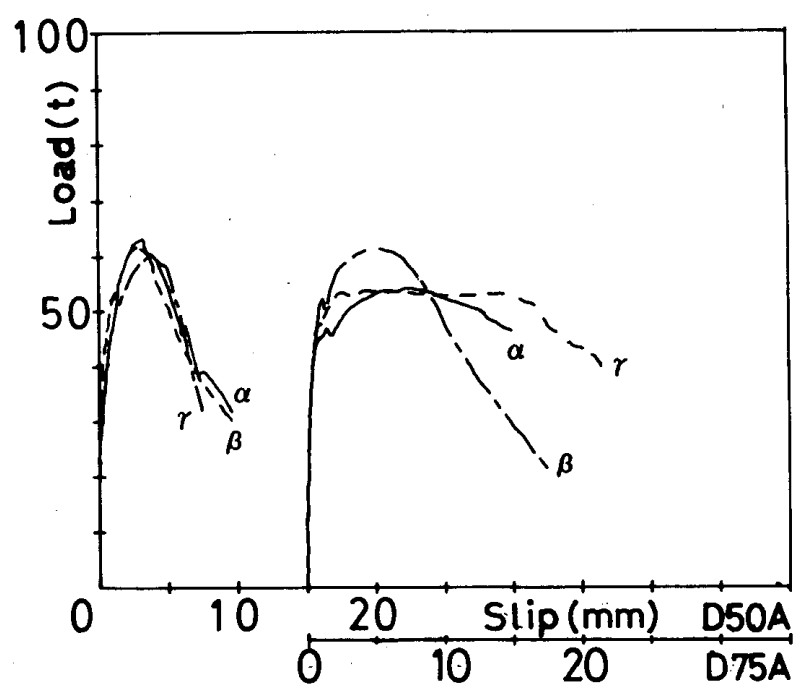

Fig.10 Load-slip relationships for specimens of series II

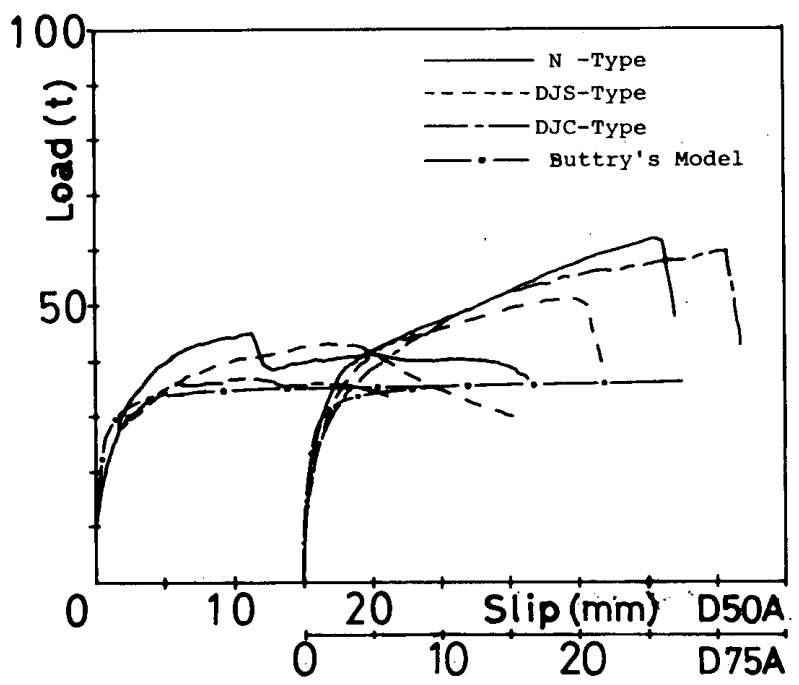

Fig. 11 Load-slip relationships for N, DJS, DJC-type specimens

ち多少でも溶接部での破断の疑いのあるものの本数を

（）内で示した。

3.2 シリーズ Пの実験結果

図一10は，シリーズ II 試験体について，スタッド コネクタの存在する溝中央で計測された相対ずれと荷重 との関係を示し， $\beta$ および $\gamma$ タイプの試験体について は，計測荷重を 2 倍にして描いたものである。

EZ 50A 419 II のシリーズでは， $\alpha, \beta, \gamma$ タイプによ る顕著な相違は見られず，耐力もほぼ等しく，破壊相も すべてコーン破壊であった。

一方, EZ 75 A 419 II シリーズでは, $\beta$ タイプの試 験体が溝上面でせん断破壊を示したにもかかわらず高い 耐力を示した。スラブを取り除いた後での観察によると， スラブ内の横筋がスタッドコネクタの上部に触れてお り，この横筋の拘束により高い耐力を示したものと思わ れる。しかしながら，EZ 50A419 II場合亡同様に， $\alpha$ と $\gamma$ の挙動に差はない。なお， $\alpha, \gamma$ の破壊相は, デッ
キプレートの変形をともなうコーン破壊であった。 $\alpha$ 夕 イプの試験体において, 上溝と下溝でのダイヤルゲージ の挙動にはまったく差異はなかった。このことは,シリー ズ川Iすの゙ての試験体においても確認された。

以上のことから次の結論を得た。

1）試験体のスラブ幅は，D50 A で $500 \mathrm{~mm}, \mathrm{D} 75 \mathrm{~A}$ で $750 \mathrm{~mm}$ で十分である。

2） 1）のスラブ幅を持つならば, $\alpha, \beta, \gamma$ のイプ による差異はなく，したがって，シリーズIIIの試験 体として，シリーズIと同じ $\alpha$ タイプを採用する ことにした。

3）シリーズIのコーン破壊を示した試験体のスタッ ドコネクタの耐力はそのまま評価でき，また，上下 の溝中のスタッドコネクタは，実験の極く最終の段 階を除き，均等に機能したものと思われる。

\section{$3.3 \mathrm{~N}$, DJS，DJC タイプの実験結果}

図一11 は，N，DJS，DJCタイプの荷重一相対ずれ 曲線を示すものである。図中, Buttry's Model*3 とある のは, 次式

$$
q=q_{s o l} \cdot \frac{80 \Delta}{1+80 \Delta}
$$

\section{$\Delta:$ 相対ずれ (inch)}

に，(1) 式を代入したものである。なお，この式は比 較的良好な近似を与えることが確認されている5)。

文献 5）の実験結果と同じく，N，DJS，DJCに顕著 な差はないものの, 75 シリーズは高い耐力を示し, また, その荷重一相対ずれ特性は, Buttry's Model と異質な 様相を示している。スタッドコネクタの長い $(L / d=$ 6.8）ことが原因と思われる。

\subsection{DA タイプの実験結果}

\section{4 .1 荷重-相対ずれ特性}

\subsubsection{1 荷重-相対ずれ曲線}

図一12 は, シリーズ而の実験結果を実験変数ごとに 取りまとめて示すものである。最大耐力の発現以後劣化 の激しい曲線（例えばNo.520, 図 (b)) がコーン破壊 に対応し，また，(No.510，図（b)）は，スタッドコネ クタの破断により酎力が決定ずけられる典型的な例であ る。後述のコーン投影面積が大きく，スタッドコネクタ の径および本数によりスタッド破断に対する余力の大き いほよ゙，コーン破壊の特性が顥著となる。

劣化の後, 再度耐力の上昇する曲線（例えば No. 708, 図 (a)) は，デッキプレートの変形をともなう支圧型の 破壊相に対応する。実験中の観察から，デッキプレート の変形が, この曲線の後半部分を特徴づけるものと思わ れる。

図一13 は, 最大荷重で無次元化した荷重を縦軸とし

*3 原典そのものは修士論文で入手しがたいが, 文献 2) に 紹介されている。 


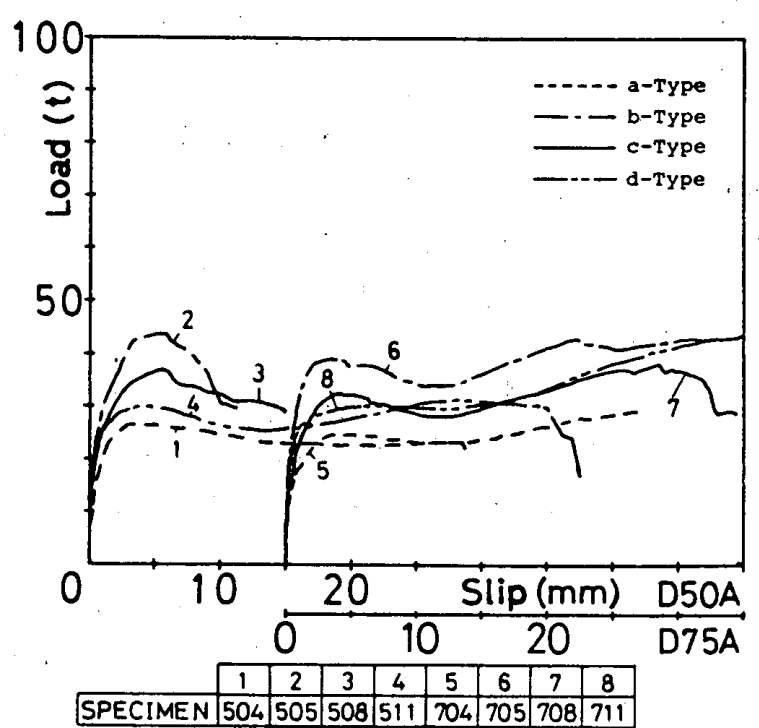

(a)

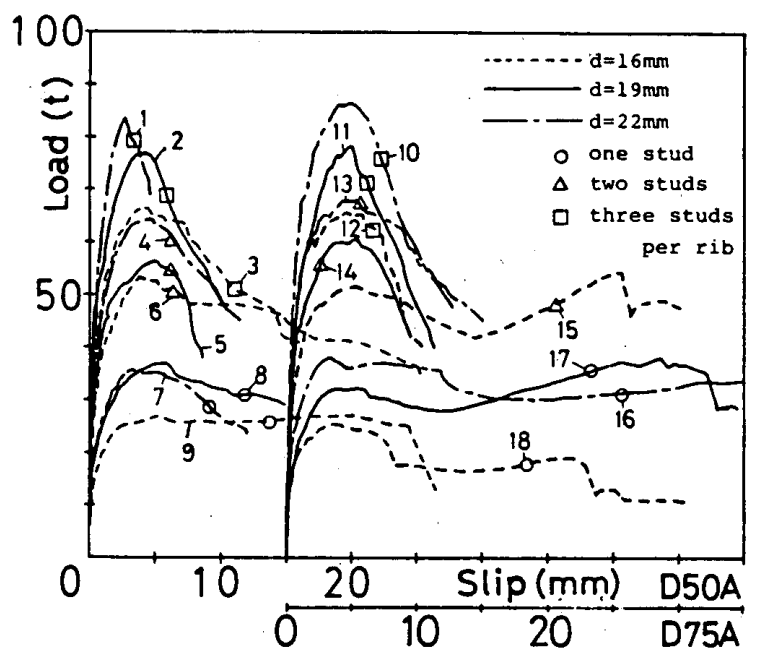

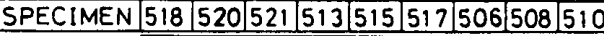

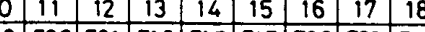

(b)

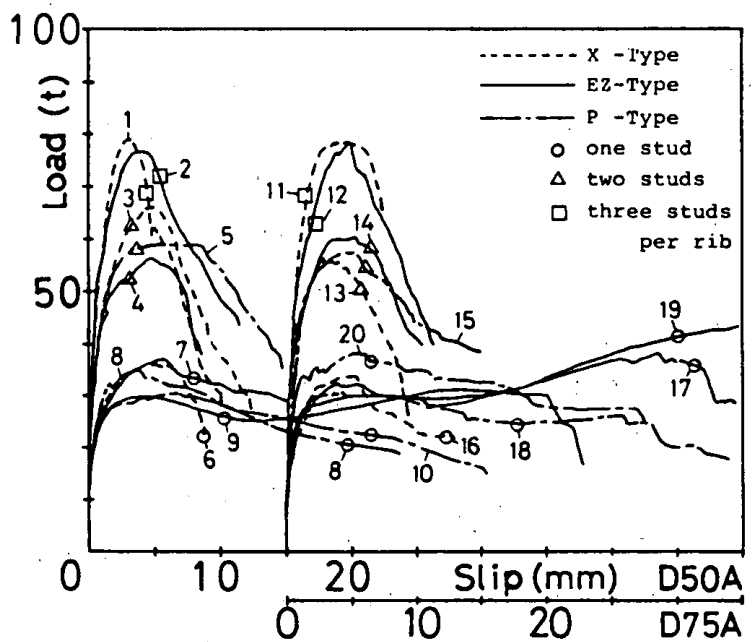

\begin{tabular}{l|l|l|l|l|l|l|l|l|l|}
\hline & 3 & 3 & 4 & 5 & 6 & 7 & 8 & 9 & 10 \\
\hline
\end{tabular}

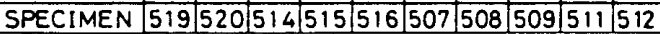

\begin{tabular}{|l|l|l|l|l|l|l|l|l|l|}
\hline 11 & 12 & 13 & 14 & 15 & 16 & 17 & 18 & 19 & 20 \\
\hline
\end{tabular}

\begin{tabular}{l|l|l|l|l|l|l|l|l|l|l|}
\hline SPECIMEN & 719 & 720 & 714 & 715 & 716 & 707 & 708 & 709 & 711 & 712 \\
\hline
\end{tabular}

(c)

Fig. 12 Load-slip relationships for DA-type specimens

$-80-$



(a) Concrete pullout failure and Rib-punching failure

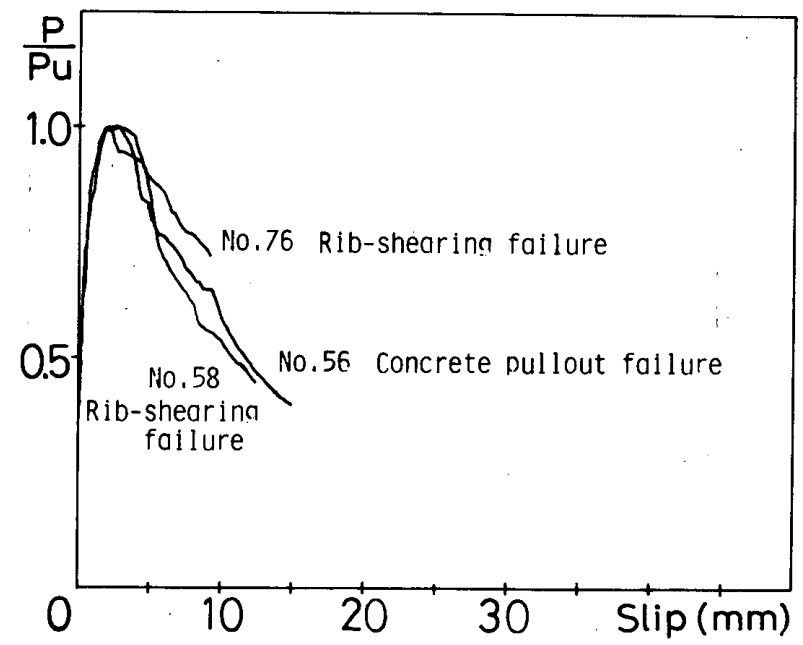

(b) Concrete pullout failure and Rib-shearing failure

Fig. 13 Load-slip relationships



Fig. 14 Test curves and equation (7) 
た荷重-相対ずれ曲線で，同図（a）は，支圧型曲線の前 半部分とコーン破壊の曲線が酷似していることを示して いる。このことから，ここでいう支圧破壊は，コーン破 壊の後，なんらかの拘束により，スタッドが直ちに抜け 出すことなくデッキプレートの変形を強制するものと思 われる。

同図（b）は，同じく，シリーズI の溝上面のせん断 破壊とコーン破壊を比較したもので，両者はよく似た曲 線となる。実験中に溝上面のせん断破壊とみとめられた 試験体は，その耐力が，後述のコーン破壊に対する耐力 式によく適合することとあわせて，その破壊相は，コー ン破壊との折衷型と考えられる。

図一12 を見るに, 今回の実験では, 総じて,ともにコー ン破壊の破壊相を示したD50Aと，それに対応するD75 A の挙動は, 耐力を含めて顕著な差がない。

表一5 の (12) 欄は, 観測された最大耐力時の相対ず れ量 $\delta_{u}$ を示すもので, 支圧型の破壊相の場合には前半 部分の最大耐力に対応する数値を示し，大変形時の最大 耐力に対応するずれ量は（）内に示した。

3.4 .1 .2 荷重-相対ずれ曲線のモデル化

荷重一相対ずれ特性を一般化するために，荷重-相対ず れ曲線のモデル化を試みた。提案するモデルは次式であ る。

$$
\frac{P}{P_{u}}=\frac{(b / a)\left(\delta / \delta_{u}\right)^{a}}{(b / a-1)+\left(\delta / \delta_{u}\right)^{b}}
$$

$P_{u}$ : 最大耐力

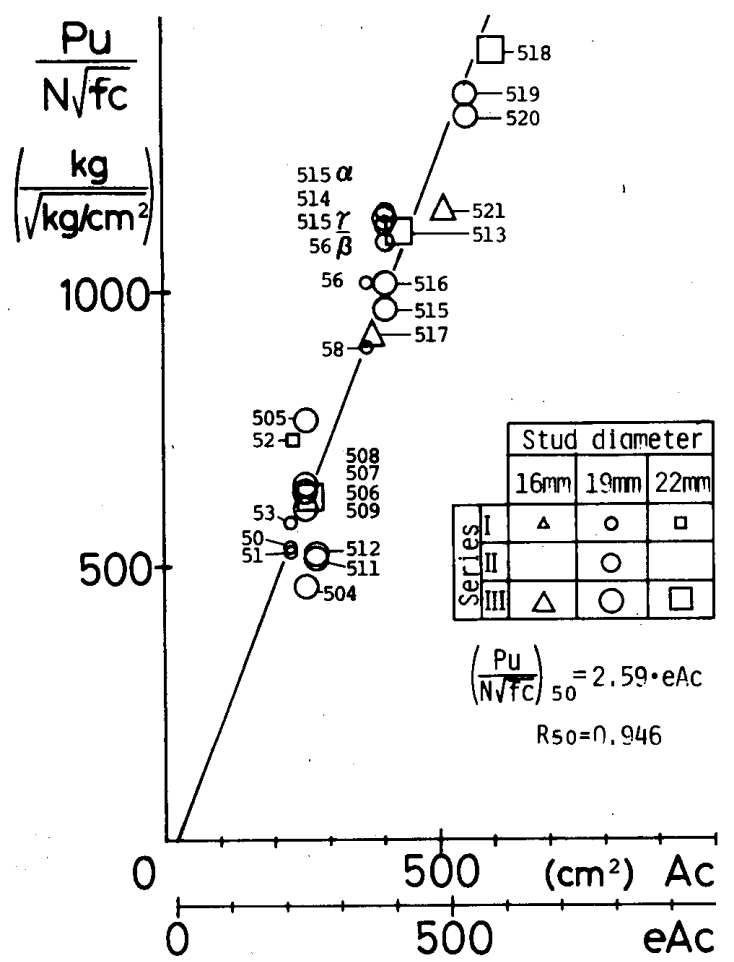

(a) $\mathrm{D} 50 \mathrm{~A}$

Fig. 16 Comparison of connector strength with projected area of cone

\section{$\delta_{u}$ : 最大耐力時のずれ量}

上式は，耐力が劣化する領域をも近似したいと考えて， また，支圧破壊型のように再度耐力が上昇する場合には 前半部分が近似し得ればよいとして定めたものであり, $\delta / \delta_{u}$ が 1 のとき，この関数は停留する性質を持つ。

図一14 は， $a ， b$ および $P_{u}, \delta_{u}$ をも変数として， 《旷 までの測定結果を参照して, 最小二乗法により求めた曲 線と実験結果とを比較するものである。図に見るように， この関数は，スタッド破断，コーン破壊，支圧破壊型の いずれの破壊相に対しても優れた近似を与える。しかし

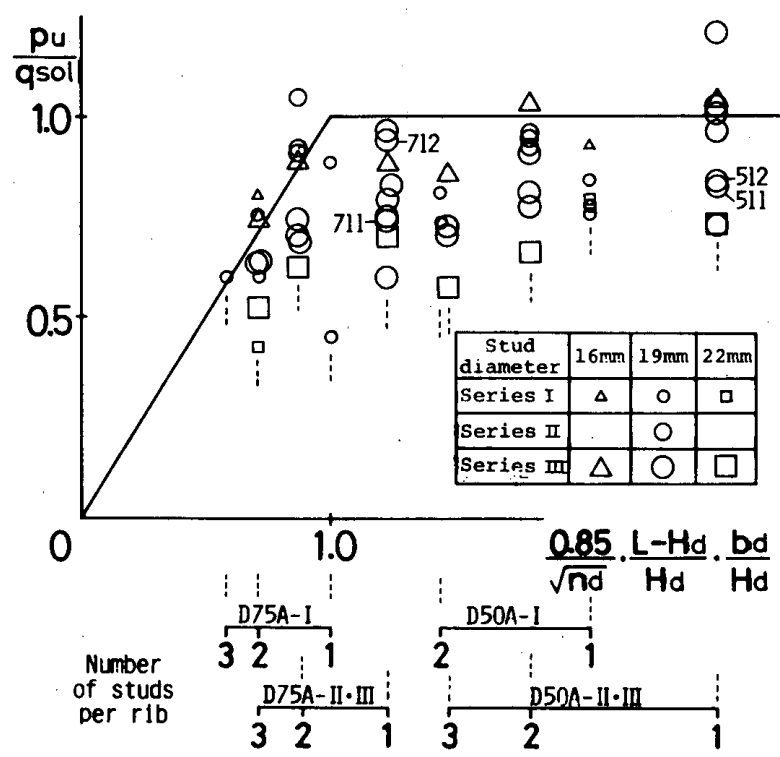

Fig. 15 Correlation with equation (2)



(b) D75 A 
ながら， $\delta_{u}$ および $a, b$ とコーン投影面積等の諸因子と の関係は，不明な点も多く今後の実験を待たざるを得な い。

表一5の（13）欄は, 得られた曲線から求めた初期剛. 性を示すものである。この初期剛性は $\left(P_{u} / N\right) / 3$ におけ る割線剛性である。

3.4 .2 耐力

\subsubsection{1 実験結果}

表一5の（11）欄は，すべての試験体について，観測 された耐力を示したものである。前述の $\delta_{u}$ と同様に, 最大耐力の発現以前に局所的な最大耐力が観察された場 合にはその数値を記し, 参考のために, 大変形時の最大 耐力を（）内の数值で示した。また，(10）欄にこの 局所的な耐力を決定づけたと考えられる破壊相を示す。 このような場合に, 以下の考察は, 発現時のずれ量を考 虑して，局所的な最大耐力とその破壊相で議論する。

\subsubsection{Fisher, J.W. 式との比較}

図一15は，（2）式すなわち $q_{r i b}$ 式と実験結果を比較 したものである。縦軸は，スタッドコネクタ一本当たり の耐力 $p_{u}$ を $q_{\text {sol }}$ 式で無次元化したものである。した がって; 本図は $q_{s o l}$ 式からの低減率を示すものである。

図は，本実験結果が（2）式を大きく下まわることを， 示している。d配置の試験体 (No.511，512，711，712) は, Fisher の実験と同じく，溝中央にスタッドコネク 夕を配置したものであるが，この配置においても， No.712（P75 A 219d） が耐力式上にあるほかは，耐力 式を著しく下まわり，（2）式の適用には限界があるも のと思われる。

なお，（2）式は，合成ばりの曲げ試験から定められ たものであることとを付言しておく。

\subsubsection{3 コーン破壊と耐力}

図一16 は，計算で得られたコーン投影面積 $A_{c}$ と $P_{u} /$ $\left(N \sqrt{F_{c}}\right),\left(P_{u}\right.$ : 最大荷重, $N$ : 試験体の全溝数）との 関係を示したものである。図中に示した回帰直線は，シ リーズIIおよび吕のコーン破壊の試験体（表-5（10）欄， 支圧破壊の前半部分もコーン破壊と認識する) から最小 二乗法により求めたものであり，その相関係数は,

$$
\begin{aligned}
& R_{50}=0.946 \\
& R_{75}=0.973
\end{aligned}
$$

ときわめて高い。

ここでいうコーン投影面積 $A_{c}$ とは，図一17 に示す， スタッドコネクタの頭部を除く薄墨部分である。同図

（b）に示したようにコーンが交差する場合には，相貫 体の表面を投影した面積とした。図は，D75Aに対して 描いたものである。

デッキプレートのタイプの違いにより，計算で得られ るコーン投影面積に差はない。なお，このコーン投影面 積 $A_{c}$ と（3）式のコーン表面積 $A_{c}^{\prime}$ との間には次なる

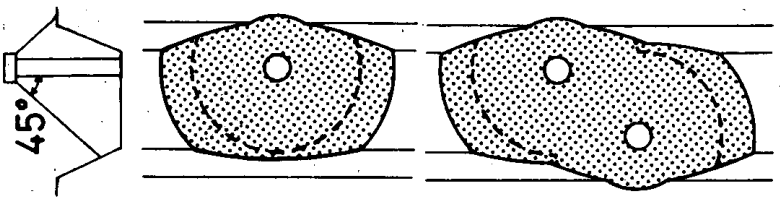

(a ) One stud

( b ) Two studs

Fig. 17 Projected area of cone

Dotted line is for the fictitious profil (Fig. 18)

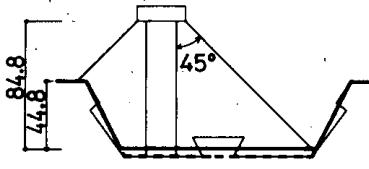

(a) D $50 \mathrm{~A}-$ II, III

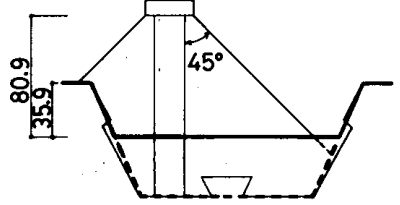

(b) D75 A-II, III
Fig. 18 Fictitious profiles for series II and III which decided for regression line to be drawn through the origin in Fig. 16

関係がある。

$$
A_{c}^{\prime}=\sqrt{2} A_{c}
$$

\subsubsection{4 有効コーン投影面積と耐力}

D50A II，IIjよびD75A II， IIIに対して，デッキプ レートの溝深さをそれぞれ, $44.8 \mathrm{~mm}$ および $35.9 \mathrm{~mm}$ に低減した図一18 に示す断面を仮想断面と仮定する。 この溝深さの低減により, 図一17に示した破線の外側 が無効な投影面積となる。この縮小された投影面積を有 効投影面積 ${ }_{e} A_{c}$ と呼ぶものとする。

今回の実験では，一溝あたりのスタッドコネクタの本 数の違いによる無効面積の差は極く僅少である*4。した がって，図一16は，D50A II，IIIおよびD 75 A II，III に対してそれぞれ一率にコーン投影面積を減ずることに より，すなわち，横軸の移動により，有効コーン投影面 積で表現されることになる。同図の下段の座標軸がそれ である。なお，図一18 の仮想断面は，コーンの裙野が 無効であると考えて, 図一16の回帰直線が原点を通る ように定めたものである。この回帰直線は，有効コーン 投影面積を用いて，次式で与えられる。

$$
\begin{aligned}
& \left(P_{u} / N \sqrt{f_{c}}\right)_{50}=2.59_{e} A_{c} \\
& \left(P_{u} / N \sqrt{f_{c}}\right)_{75}=2.37_{e} A_{c}
\end{aligned}
$$

シリーズI とIIおよび吕とはスタッドコネクタの長さ が異なる。図一16 中に示されたシリーズ I の実験結果 は，仮想断面に対するスタッドコネクタの首下長さが図 - -18の (a)，(b) とそれぞれ等しくなるものと仮定し 定めた仮想断面に対する有効コーン投影面積を用いて描

*4この関係は通常の範囲で成り立つ。ただし，溝幅やスタッ ドコネクタのゲージ間隔が極端に大きい場合には成立しな い。

*5 もとの断面から仮想断面への変換によるコーンの無効投 影面積はシリーズ II， III と異なる。したがって，図一16 において，もとの座標軸は参照できない。 
いたものである゙5。図から実験中に溝上面でせん断破壊 と観察された試験体を含めて，先に求めた回帰直線でよ く表現できることがわかる。

なお，この仮想断面の溝深さは，種々の要因に左右さ れるものと考えられるが，著者等の感触では，上述のよ うに，主としてスタッドュネクタの首下長さに依存する ものと思われる。しかしながら，今回の実験では，実験 変数として積極的にスタッドコネクタの首下長さに注目 したわけではなく，また，固定された実験変数も多いこ とから，仮想断面の溝深さを具体的に提案することは差 し热え，ここでは，実験より得た仮想断面の溝深さとそ

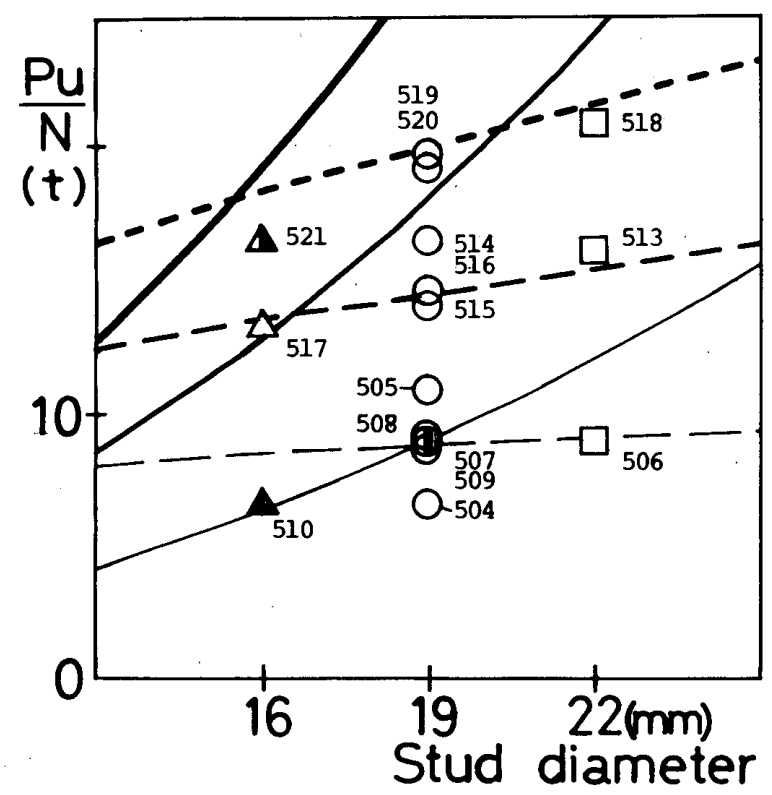

$\triangle O \square$ Concrete pullout failure $\Delta \mathbf{0}$ concrete pullout failure (One or two studs failed) - Stud fallure
の思想を報告するのにとどめるものとする。

\subsubsection{5（1）式および（8）式と耐力}

図一19 は，（1）式および（8）式とシリーズயIIの実 験結果を比較したものである。d配置は有効コーン投影 面積が図一19 中の曲線で与えられないことから除外し た。

結果として，コーン破壊が支配する領域での試験体が 多いことになったが，（1）式および（８）式のうち小 さいほうの值が耐力を与えるものと思われる。

コーン破壊により耐力が決定づけられた武験体のう ち，2曲線の交点に近いものの中に，大変形時にスタッ

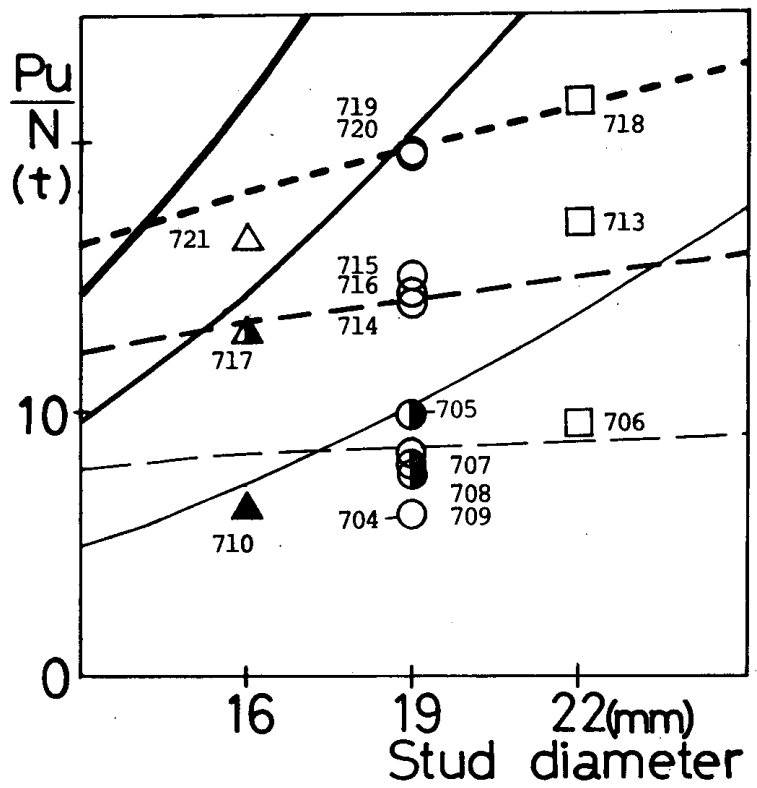

\begin{tabular}{|c|c|c|c|}
\hline $\begin{array}{l}\text { Number of studs } \\
\text { per rib }\end{array}$ & 1 & 2 & 3 \\
\hline $\begin{array}{c}\text { Equation(1) } \\
\text { Equation(8) }\end{array}$ & -- & --- & --- \\
\hline
\end{tabular}

Fig. 19 Correlation with equation (1) and ( 8 )

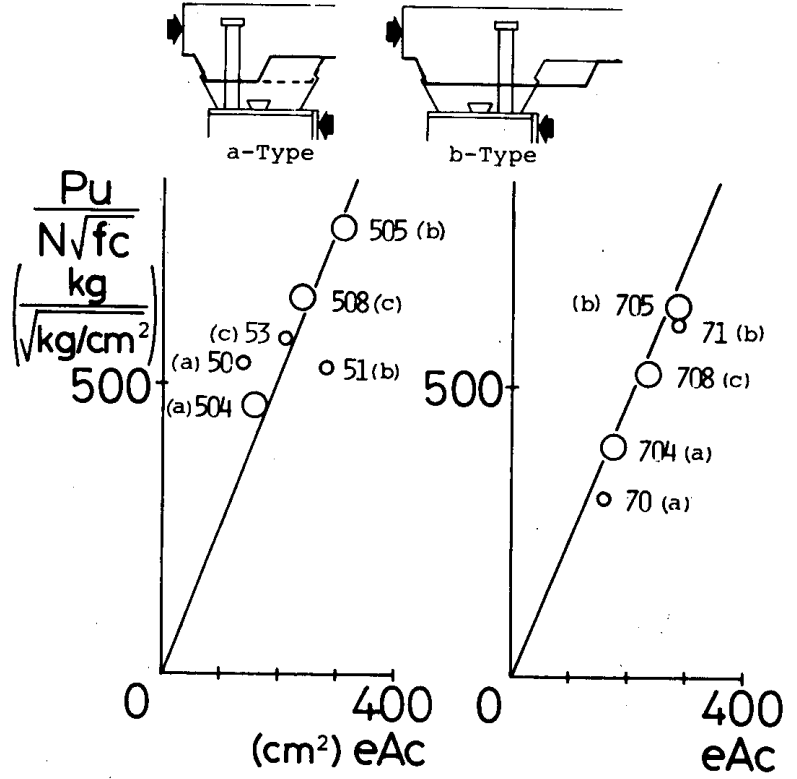

Fig. 20 Comparison of connector strength of a, b, c-type

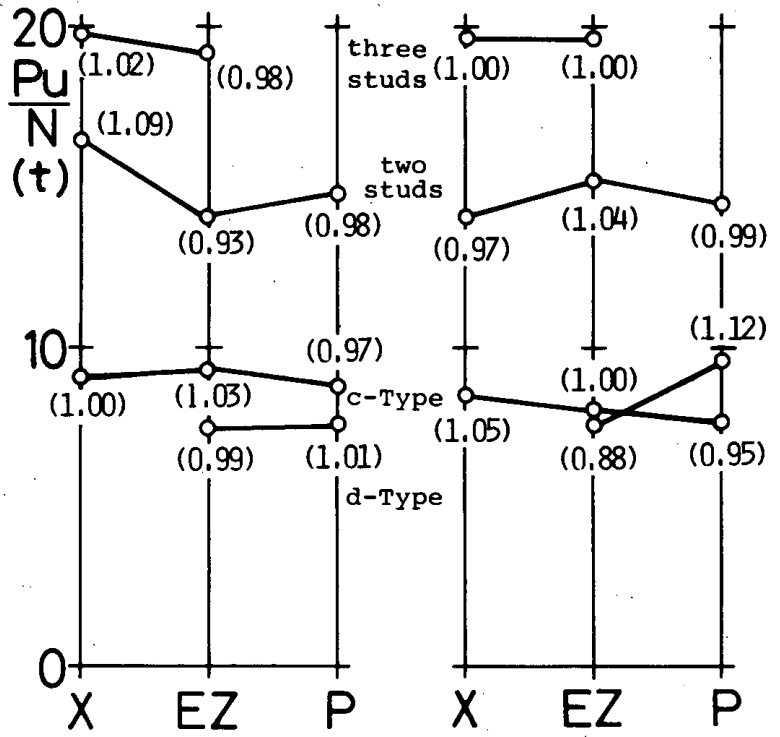

(a) $\mathrm{D} 50 \mathrm{~A}-$ III

(b) D75 A-III

Fig. 21 Comparison of connector strength of EZ, X, P-type 
ドコネクタの破断するものが存在し（山の印），また， 荷重-相対ずれ曲線もコーン破壊の特性が薄らぐ傾向に ある。

3.4.2.6 スタッドの配置形態 $(\mathrm{a} \sim \mathrm{d}$ 配置) と耐力 図一20は, EZ タイプの試験体において, 配置の影響 を考察したものである。図は, c 配置の耐力が $\mathrm{a}$ 配置と b 配置の平均值にほぼ等しいことを示している。

なお，付言すると，横軸は，試みに図一18の仮想断 面の溝幅を拡大もしくは縮小し, スタッド軸を中心に対 称とした新たな仮想断面に対する有効コーン投影面積で ある。図一20 中の直線は, 図一16 中の直線をそのまま 示したものである。この仮説の評価には, さらなる研究 が必要と考える。

\subsubsection{7 デッキプレートの形状と耐力}

図一21 は，デッキプレートの形状の違いによる耐力 への影響を考察したものである。図一21 中の数值は平 均値に対する比率を示したものである。荷重-相対ずれ 曲線に本質的な違いがないことと考え合わせて、デッキ プレートの形状の違いは，耐力に顥著な影響を与えない ものと思われる。

\section{4. 結 び}

序で述べたように，デッキプレートの溝に埋め込まれ たスタッドコネクタの挙動には未解明な部分が多く残さ れてきたと思われる。著者等は，コーン破壊の場合の耐 力を初めとし, 本実験から得られた多くの知見により, 未解明部分の究明に貢献し得たものと考えている。

本研究で得られた結論を要約すると次のとおりであ る。

1）破壊相として，スタッドコネクタの破断・コンク リートのコーン破壊・溝上面のせん断破壊・デッキ プレートの変形を伴う支圧破壊か観察された。荷重 一相対ずれ特性は破壊相により異なり，コーン破壊 が卓越する場合には, 最大耐力以降の耐力低下が顕 著である。

なお，デッキプレートのせいと溝幅の比の大きな 試験体において, 溝の転げる破壊相が平野等の実 験)により観察されていることを報告しておく。

2）デッキプレートの変形を伴う支圧破壊の荷重-相 対ずれ曲線の前半部分の特性は, コーン破壊の特性 と同じである。また，この前半部分の耐力は,コー ン破壊に対する耐力式に適合する。

3）この前半部分を含めて, コーン破壊の荷重一相対 ずれ曲線は，（7）式の形で与え得る。なお，この 式は,スタッド破断に対しても良好な近似を与える。

4）、コーン破壊の場合に, 耐力がコーン投影面積に比 例するという Hawkins, N. M. 等の考え方は, 溝底 をかさ上げした仮想断面に対する投影面積の導入に より，さらに適合性が高くなる。
5）DA タイプにおけるスタッド破断の場合の耐力 は, Fisher, J.W.による $q_{s o l}$ 式，すなわち（1） 式に適合する。

6) Fisher, J.W.による $q_{r i b}$ 式，すなわち（2）式 は，本実験においては適合しなかった。

7）スタッドコネクタのずれ耐力は，スタッド破断に 対する（1）式と，コーン破壊に対する（8）式の うち小さい方の值で表せる。

8）合成ばりにおいて実用的である $\mathrm{c}$ 配置の耐力は, $a$ 配置と $b$ 配置の耐力の平均值となり, 妥当な配置 と考えられる。

9）デッキプレートの形状の違いは，耐力に顥著な影 響を与えないものと考えられる。また，P夕イプと の比較から，EZタイプおよびXタイプのデッキプ レートに存在する鍵溝やエンボス等は耐力, 剛性に 影響を与えないと思われる。

10） N，DJS，DJCタイプは, 過去の実験5)か, Fisher, J.W. の報告 ${ }^{2)}$ と同様の挙動が予想された が、スタッドコネクタの長い試験体ではこれと異な る様相を示した。

以上が本論文の結論であるが, 耐力を決定づける破壊 相は，スタッドコネクタの長さやデッキプレートの断面 形状等の諸因子により異なるものと思われる。

このことは, デッキプレートのない等厚スラブ中のス タッドコネクタにも当てはまるものと考えられる。

Fisher, J.W.の提案による (1) 式は, スタッドコ ネクタやその間隔等の諸元を実用範囲に想定し，実験結 果から耐力の決定要因を考究することなく統計学的に定 めたものである。したがって，著者等は，この式を実用 上優れた耐力式と認識するが，その運用には適用限界を 適切に意識する必要があると考えている。

デッキプレートの有無にかかわらず, 適用限界を拡張 し，スタッドコネクタの配置設計に自由度を与えるため にも, 破壊相の洗い出しとそれに対応する耐力式の究明 が大切であると思われる。

\section{謝 辞}

実験の実施に当たっては, 東京理科大学大学院生伊藤 倫夫氏をはじめ卒業研究生諸氏の御協力をいただいた。 ここに厚く御礼申し上げます。

\section{引用文献}

1）平野道勝，穂積秀雄ほか：床鋼板の溝に埋込まれたスタッ ドコネクタの押抜実験, 日本建築学会大会学術講演梗概 集, 昭和 60 年

2) Fisher, J. W., et al. : Shear strength of Stud Connector in Lightweight and Normal-Weight Concrete, AISC Eng. J. April, 1971

3) Fisher, J.W., et al. : Composite Beams with Formed steel Deck, AISC, Eng. J., First Quarter, 1977 
4) Hawkins, N. M., Mitchell, D. : Seismic Response of Composite Shear Connections, ASCE, J. St. Eng., September, 1984

5）平野道勝, 穂積秀雄ほか：床鋼板つきコンクリートスラ ブに埋込まれたスタッドコネクタの押拔試験, 日本建築 学会論文報告集, 第 281 号・昭和 54 年 7 月

6) Viest, I. M. : Investigation of Stud Shear Connector for Composite Concrete and Steel T-Beams, J. ACI, April, 1956

7) AISC : Specification for the Design, Fabrication and
Erection of Structural Steel for Building, 1978

8) 日本建築学会：各種合成構造設計指針 - 同解説第 1 編, 合成ばり構造設計指針・同解説, 昭和 60 年

9) 同上, 第 4 編, 各種アンカーボルト設計指針・同解説

10) ECCS : Composite Structures, 1981

11）日本道路協会：道路橋示方書 - 同解説 I - II, 昭和 60 年 6 月

12) AASHTO : Standard Specifications for Highway Bridges, 1977

\title{
SYNOPSIS
}

UDC : 69. $025: 624.072 .2 .012: 620.1$

\section{PUSHOUT TESTS OF STUD CONNECTORS EMBEDDED IN THE RIBS OF DECKPLATES FOR COMPOSITE SLABS}

\author{
by Dr. MICHIKATSU HIRANO, Professor of Science Univ. \\ of Tokyo, HIDEO HOZUMI, Research Associate of Scien- \\ ce Univ. of Tokyo, MANABU ITOH, Graduate Student of \\ Science Univ. of Tokyo, HIROSHI FUJIOKA, Manager \\ of Nippon Steel Metal Products Co., Ltd., YOSHIO \\ ENMEI, Associate Manager of Nippon Steel Metal Pro- \\ ducts Co., Ltd., YoshIMITSU ITOH, Assistant Mana- \\ ger of Nippon Steel Metal Products Co., Ltd., Members \\ of A.I. J.
}

This paper describes the rigidity and strength of stud connectors based on the results of tests with 62 pushout pieces.

The deckplate tested is for application to composite slabs and has a Lock rib in the center of its rib section. Since it is practical to weld the stud connectors by avoiding the Lock rib, we have arranged the stud connectors as in Figure 6.

Among the considerable information we have received from the test results, the following 3 points are of particular significance.

1. In Figure 9, we have observed various failure modes. As shown in Figure 13-(a), the characteristics observed in the first half of the load-slip relationship of rib punching failure, which accompanies deckplate deformation, are the same as those resulting from concrete pullour failure.

2. The load-slip relationship of concrete pullout failure, and the first half of rib punching failure, are given in formula $(7)$.

3. The opinion expressed by N.M. Hawkins, that strength is proportionate to pullout surface area, is made even more applicable by subtracting the skirt of pullout surface from projected pullout surface area. The coordinate axis shown at the bottom of Figure 16 represents effective projected pullout surface area. Test results show that, effective projected pullout surface area may be given by projected pullout surface area of the hypothetical section shown in Figure 18. 